\title{
Flexible Work Arrangements from Generation and Gender Perspectives: Evidence from Lithuania
}

\author{
Ramune Ciarniene, Milita Vienazindiene
}

Kaunas University of Technology

K. Donelaicio st. 73, LT-44029, Kaunas, Lithuania

E-mail.ramune.ciarniene@ktu.lt

Aleksandras Stulginskis University

Studentu st. 11, LT-53361 Akademija, Kauno r., Lithuania

E-mail.milita.vienazindiene@asu.lt

cross $^{\text {ref }}$ http://dx.doi.org/10.5755/j01.ee.29.1.19247

The demand for employee-oriented and individualized work arrangements and practices that permit temporal and spatial flexibility in work processes and help to fit changing personal needs and environmental conditions is constantly increasing. A growing number of private companies and public organizations are adopting flexible work arrangements (FWAs) to help employees balance their work-family demands, and companies cope with variations in demand, reduce expenses, and be more attractive for employees. Employees representing different age and sex groups have different expectations and priorities towards work, and, it is likely that they evaluate and respond to flexible work practices differently as well. The paper investigates how different genders and generations evaluate and respond to flexibility at work. Empirical research was conducted in Lithuania, 316 employees participated in the poll. According to the research, high expression of flexible work arrangements is observed in Lithuanian organizations. Flexible work schedule and flexible work load are dominating in the organizations. Work flexibility in terms of time and load is more attractive to employees than flexibility in terms of working place. Research revealed that representatives of generations $B$ and $Y$ are most satisfied in the forms of flexible work arrangements applied in their organizations. It was also revealed that women tend to work flexibly slightly more than men; women emphasize coordination of work and family interests, decrease of stress, positive effect on health, time and cost saving, and ability to earn according to their needs.

Keywords: Flexible Work Arrangements (FWAs); Work-Family Conflicts; Generation; Gender.

\section{Introduction}

The global economy, rapidly evolving technologies, changing market conditions, big variations in demand of products and services, aging population and changes in demography and workforce composition call for the changes in work processes and arrangements.

Changes in family structure and paid labour participation patterns, fast growing number of dual-earner couples, single parents, and supervisory responsibilities lead to the situation when employees face a lot with the challenge to manage work and family demands across the all life course (McNall, Nicklin \& Masuda, 2010; Allen \& Eby, 2016).

Work-family balance plays an important role for individuals, organizations, and society in general, and attracts attention from researchers analysing different intersections of work and family domains (McNall, Nicklin \& Masuda, 2010).

Technological advancements change the way work is done as well as where and when it can be done blurring the boundaries between work and home. Work is no longer entirely linked to a distinct physical location (Allen \& Eby, 2016).

The changing world of work implies the necessity to move away from older, more traditional, less flexible ways of working that are now past their sell-by date (Lake, 2013).

Increased attention has been focused on workplace flexibility, because employers are beginning to frame workplace flexibility as a potential benefit for both the organization and employees (Pitt-Catsouphes \& MatzCosta, 2008).

In recent years, a growing number of private and public companies have adopted flexible work arrangements (FWAs) to help employees balance their work-family demands.

Flexible work arrangements are claimed by different researchers worldwide as a quite appropriate way for companies to cope with variations in demand, reduce expenses, and be more attractive for employees.

When employees have the flexibility at work they need, they gain in the form of higher employee engagement, less work overload, better work-family balance, and better mental health (Pitt-Catsouphes, MatzCosta \& Besen 2009).

During the past decade different types of flexible work arrangements, their usage and benefits have been analysed by scientists all over the world.

Research works of Gajendran and Harrison (2007), Shockley and Allen (2007), Pitt-Catsouphes and MatzCosta (2008), Casper and Harris (2008), Pitt-Catsouphes, 
Matz-Costa and Besen (2009), Russell, O'Connell and McGinnity (2009), Joyce et al. (2010), Kelliher and Anderson (2010), McNall, Nicklin, and Masuda (2010), Eldridge and Nisar (2011), Carlson et al. (2011), Giannikis and Dimitrios (2011), Dutcher (2012), Lee and DeVoe (2012), Booth and van Ours (2013), Lake (2013), Cotti, Haley, and Miller (2014), Possenriede (2014), Gordon (2014), Allen and Eby (2016), Choo, Desa, and Asaari (2016), Heathfield (2016), Taylor (2016), Hyondong and Yaping (2016), Townsend, McDonald, Cathcart (2016), Stirpe and Zarraga-Oberty (2017) and many others have been exploring different work flexibility issues.

A lot of studies on work flexibility examining the availability and utilization of different flexible work options and practices mostly had a "more is better" perspective (Pitt-Catsouphes, Matz-Costa, 2008). Such a perspective overlooks the concept of suitability of flexible work practices to different employees with different demographic profiles.

According to Pitt-Catsouphes, Matz-Costa and Besen (2009), Stirpe and Zarraga-Oberty (2017) employees representing different age and sex groups have different priorities and expectations at work.

During past years many research works have been conducted about work practices, gender and generational differences. Pitt-Catsouphes and Matz-Costa (2008), Toblize (2008), Pitt-Catsouphes, Matz-Costa and Besen (2009), Sun and Wang (2010), Benson, Brown (2011), Abrams and Von Frank (2014), Buonocore, Russo and Ferrara (2015), Lub et al. (2016), Fry (2015), Lub, Bal, Blomme and Schalk (2016) were examining generational differences and different attitudes of the main generations towards work.

Giannikis and Dimitrios (2011), Thompson, Payne and Taylor (2015), Hyondong and Yaping (2016) were analysing attitudes towards work options between men and women.

Despite big interest in the FWAs, gender and generational differences in general, little research has been conducted on how employees representing different genders and generations treat flexible work arrangements and what are their opinions, priorities, satisfaction and expectations towards flexible work options.

The paper aims to disclose how different genders and generations evaluate and respond to different types of flexible work arrangements.

Methods of the research: systematic and comparative analysis of scholarly literature, survey research, logical abstraction and conclusion generation.

\section{Theoretical Background}

Demand for employee-oriented and individualized work arrangements and practices that permit temporal and spatial flexibility in work processes and help to fit changing personal needs and environmental conditions is constantly increasing.

According to Pitt-Catsouphes, Matz-Costa, (2008), flexibility at the workplace has multiple dimensions, including policies and practices; attitudes and values; work design and employment decisions; interpersonal communications and interactions that construct and reconstruct the meanings and experiences of flexibility.
Broadly defined, flexible work arrangements encompass adjustments to the timing, location or tasks of work; direct provision of care giving and health benefits; and monetary and informational support for non-work roles.

The most of researchers agree on two broad groups in terms of flexibility: temporal flexibility and place flexibility.

Based on Pitt-Catsouphes, Matz-Costa and Besen (2009), and Giannikis and Dimitrios (2011) these two broad groups can be in more details categorised into the following five subgroups:

1. Flexibility in the scheduling of hours (flex-time, compressed workweek, shift arrangements).

2. Flexibility in the number of hours worked (e.g., part-time work, job sharing).

3. Flexibility in the place of work (working at home, at a satellite location).

4. Flexibility in leave arrangements or options for time of (parental leave, special leave, unpaid leave).

5. Other options (e.g., control over the timing of breaks).

Flexible work structures can have different combinations of temporal and place flexibility. According to Thompson, Payne and Taylor (2015) three different combinations of temporal and place flexibility should be emphasized:

- flex-time without flex place;

- flex place without flex-time; and

- flex place with flex-time.

A flex-time arrangement without place flexibility permits employees to alter temporal, but not physical boundaries around work. When employees have discretion over where they work but not when they work, they have the option to alter physical, but not temporal boundaries. In case of both place and temporal flexibility employees have discretion over both temporal and physical work boundaries (Thompson, Payne \& Taylor, 2015).

Flexible work arrangements can also be categorised according to whether they are longer term, more formalised arrangements or short-term, informal arrangements (Townsend, McDonald \& Cathcart, 2016).

There is no doubt that employees of all ages and across different career stages more or less seek options for work flexibility.

According to the research of Pitt-Catsouphes, MatzCosta and Besen (2009), over seventy-eight percent of respondents reported that having access to flexible work options contributes to their success as employees to a "moderate" or "great extent". FWAs have been cited as key in the effort to help employees manage competing work and family domains, and attain a balance between work and personal life in today's 24/7 global economy (Possenriede, 2014).

But work flexibility is important not only from employee perspective. Various types of flexible work practices give benefits for both employees and employers.

Analysis of theoretical research works and empirical studies of Gajendran and Harrison (2007), Shockley and Allen (2007), Casper and Harris (2008), Pitt-Catsouphes and Matz-Costa (2008), Pitt-Catsouphes, Matz-Costa and Besen (2009), Joyce et al. (2010), Kelliher and Anderson (2010), McNall, Nicklin and Masuda (2010), Carlson et al. (2011), 
Eldridge and Nisar (2011), Dutcher (2012), Lee and DeVoe (2012), Booth and van Ours (2013), Lake (2013), Cotti, Haley and Miller (2014), Possenriede (2014), Gordon (2014), Ashoush, Elsayed and Younis (2015), Allen and Eby (2016), Choo, Desa and Asaari (2016), Heathfield (2016), Taylor (2016), Stirpe and Zarraga-Oberty (2017) let to reveal the main advantages of flexible work arrangements (see table 1).

Table 1

The Main Advantages of Flexible Work Arrangements

\begin{tabular}{|c|c|}
\hline Point of view & Advantages \\
\hline $\begin{array}{l}\text { Employee } \\
\text { view }\end{array}$ & $\begin{array}{l}\text { - Better work-life balance; } \\
\text { - Less rush-hour commutes; } \\
\text { - Reduced consumption of time and fuel; } \\
\text { - Money saved on going out for lunch; } \\
\text { - Decreased external childcare hours and costs; } \\
\text { - Increased feeling of personal control over work } \\
\text { schedule; } \\
\text { - Ability for people to work when they accomplish } \\
\text { most; } \\
\text { - Possibility to escape from the disruptions of the } \\
\text { - Increased job performance and productivity; } \\
\text { - Higher job satisfaction and commitment; } \\
\text { - Reduced employee burnout; } \\
\text { - Lower levels of strain; } \\
\text { - Positive effect on health outcomes. }\end{array}$ \\
\hline $\begin{array}{l}\text { Organizational } \\
\text { view }\end{array}$ & $\begin{array}{l}\text { - Activities matched according to customer demand, } \\
\text { better customer coverage; } \\
\text { - Increased ability to attract, retain and motivate } \\
\text { employees; } \\
\text { - Increased employee morale, engagement, and } \\
\text { commitment; } \\
\text { - Reduced absenteeism and tardiness; } \\
\text { - Lower turnover rates; } \\
\text { - Increased job performance; } \\
\text { - Increased productivity and profitability; } \\
\text { - More efficient use of equipment and facilities; } \\
\text { - Saving on office space, furniture, equipment, and } \\
\text { - electricity; } \\
\text { - Saving on water, coffee, paper towels, and similar; } \\
\text { - Family-friendly employer image. }\end{array}$ \\
\hline
\end{tabular}

The main benefits of FWAs for employee and employer can be considered through different dimensions: economic, environmental, social, psychological, and health issues.

Instituting flexible work practices companies differ quite a lot in the scale of flexible work practices' adoption. Gordon (2014) distinguishes three types of companies regarding workplace flexibility issues: flexible/favourable, flexible/contradictory, and rigid. A company is considered to be a flexible if three or more FWAs are being used and workplace culture supports the use of FWAs. A company is considered to be inflexible or rigid if one or none FWAs are used. Flexible/contradictory companies overlap with flexible/favourable firms with regard to flexibility for employees but not with its workplace culture (Gordon, 2014).

If an organization offers a wide range of flexible work options, but these options and practices do not fit to the needs of the company's employees, then they cannot be considered as effective. Specific types of workplace flexibility that work for one organization might not be the most effective approach for another one (Pitt-Catsouphes, Matz-Costa and Besen, 2009).

Employees with different demographic profiles, e.g., sex, age, marital status, family size, and others have different priorities and expectations at work (Pitt-Catsouphes, MatzCosta \& Besen, 2009; Stirpe \& Zarraga-Oberty, 2017). If so, likely, they evaluate and respond to flexible work practices also differently.

Flexibility fit is understood as employees' subjective assessment of the degree to which the flexibility afforded to them at their workplace meets their particular needs and circumstances (Pitt-Catsouphes \& Matz-Costa, 2008). Flexibility fit also means the extent to which flexible work options promote employee effectiveness at work and at home (Pitt-Catsouphes, Matz-Costa \& Besen, 2009).

Giannikis and Dimitrios (2011) found out that attitudes towards flexible work options are dependent on gender, sector of employment and prior participation in a flexible work scheme. According to their research, women, public sector employees and employees who have participated in FWAs are more likely to perceive more benefits with regard to the use of work flexibility.

Gender role theory explains that men and women invoke different personal identities in their work-family demands. Although both men and women are interested in flexible workplace policies, the likelihood of using a policy and the nature of the policy used differ between men and women (Thompson, Payne \& Taylor, 2015). Hyondong and Yaping (2016) disclosed that female managers facing workfamily conflict had greater demand for FWAs.

According to Pitt-Catsouphes and Matz-Costa (2008), the types of flexibility that would meet the needs of an older worker may be very different than the types of flexibility that would meet the needs of mid-life workers or younger workers.

Dependence to one or another generation can make influence on priorities and expectations regarding flexible work options, as generational differences exist in people's mental schemas about the world they live and work in (Lub et al., 2016). The concept of generation refers to an aggregate of people differentiated from others by their age (Sun \& Wang, 2010). A generation, according to Tolbize (2008) can be defined as an identifiable group that shares birth years, age, location, and significant life events at critical developmental stages.

Working age people now fall into four main generations: the Traditional generation; the Baby Boom generation; Generation X; and Generation Y (Abrams, Von Frank, 2014). The Traditional generation is the oldest generation in the workplace, although most are now retired. According to the estimations of Pew Research Centre (Fry, 2015), more than one-in-three workers today are Millennials, and they have already surpassed Generation X to become the largest share of the American workforce. Baby Boom generation takes about 29 percent of workforce and together these three groups form 98 percent of the nowadays workforce structure.

Based on the analysis of research works of Toblize (2008), Pitt-Catsouphes, Matz-Costa and Besen (2009), Benson, Brown (2011), Abrams and Von Frank (2014), Buonocore, Russo and Ferrara (2015), Fry (2015), Lub, Bal, Blomme and Schalk (2016), table 2 presents the main characteristics, values and attitudes towards different aspects of work of employees representing the main generations. 
Generations and Their Characteristics

\begin{tabular}{|c|c|c|c|}
\hline $\begin{array}{c}\text { Traditional or Silent generation } \\
\text { Born: } 1922 \text { to } 1943 \\
\end{array}$ & $\begin{array}{l}\text { Baby Boom generation } \\
\text { Born: } 1944 \text { to } 1964\end{array}$ & $\begin{array}{c}\text { Generation } X \\
\text { Born: } 1965 \text { to } 1981 \\
\end{array}$ & $\begin{array}{l}\text { Generation Y or Millenials } \\
\text { Born: } 1982 \text { to } 2002 \\
\end{array}$ \\
\hline $\begin{array}{l}\text { Family oriented and patriotic; } \\
\text { Thorough and hardworking; } \\
\text { Believed strongly in lifetime } \\
\text { employment; } \\
\text { Loyal to company and profession; } \\
\text { Respect authority; } \\
\text { Like formality and a top down } \\
\text { chain of command; } \\
\text { Uncomfortable with conflicts; } \\
\text { Prefer to make decisions based on } \\
\text { what worked in the past; } \\
\text { Averse to risk; } \\
\text { Strongly committed toward } \\
\text { teamwork and collaboration; } \\
\text { Less use flexible work options } \\
\text { when compared to the other } \\
\text { generation groups. }\end{array}$ & $\begin{array}{l}\text { Optimistic and conflict avoidant; } \\
\text { Interested in preserving } \\
\text { relationships, team-oriented; } \\
\text { Workaholic; } \\
\text { Loyal to the company; } \\
\text { Believe in paying their dues and } \\
\text { step-by-step promotion; } \\
\text { Like collaboration and group } \\
\text { decision-making; } \\
\text { Respect authority, hierarchy and } \\
\text { chain of command; } \\
\text { More process- than result-oriented; } \\
\text { Confident task completers; } \\
\text { Strong work ethic and high job } \\
\text { involvement; } \\
\text { Seek for job security; } \\
\text { Value health, wellness, personal } \\
\text { growth and personal satisfaction. }\end{array}$ & $\begin{array}{l}\text { Independent, individualistic and 'me'- } \\
\text { oriented; } \\
\text { Autonomous and self-reliant; } \\
\text { Entrepreneurial, pragmatic and } \\
\text { creative; } \\
\text { Have strong technical skills; } \\
\text { Value continuous learning and skill } \\
\text { development; } \\
\text { Ready to question authority; } \\
\text { Adaptable to change; } \\
\text { Results focused; } \\
\text { Impatient, not willing to wait for } \\
\text { promotions; } \\
\text { Expect to get rewards immediately; } \\
\text { Less loyal to organizations and more } \\
\text { loyal to the profession; } \\
\text { Can tolerate work as long as it is fun; } \\
\text { Assume every job is temporary; } \\
\text { Money does not necessarily motivate; } \\
\text { Have strong feelings of loyalty } \\
\text { towards family and friends; } \\
\text { Desire for a work-life balance; } \\
\text { Prefer flexible schedules. }\end{array}$ & $\begin{array}{l}\text { Independent, optimistic, and self- } \\
\text { confident; } \\
\text { Purport to be entrepreneurial; } \\
\text { Embrace diversity; } \\
\text { Are multi-taskers; } \\
\text { The most highly educated generation; } \\
\text { Adaptable to change; } \\
\text { Are in comfort with technologies; } \\
\text { Good at communicating through } \\
\text { electronically based interaction; } \\
\text { Lack skills to communicate with face } \\
\text { to face; } \\
\text { Value team work and collective } \\
\text { action; } \\
\text { Value training; } \\
\text { Less committed to their organization; } \\
\text { Would change the job as they like; } \\
\text { Not necessary look for jobs which } \\
\text { have stable income; } \\
\text { Seek flexibility; } \\
\text { Desire a more balanced life. }\end{array}$ \\
\hline
\end{tabular}

Disclosed gender characteristic and differences towards work itself and work practices and policies lead to possible different needs and expectations regarding flexible work arrangements.

\section{Research Methodology}

Research goal was to disclose attitude of different generations and genders to flexible work practices.

Research methods. The survey research method was used for the study. On the basis of scientific literature analysis the empirical research instrument in the form of a questionnaire was created. The questionnaire was designed as a combination of seven closed-ended type questions that were extended into 65 statements, representing three building blocks. The first block of questions represented the main demographic characteristics, especially generation and gender. The second block was devoted to disclose the manifestation of flexible work practices in Lithuania's companies. 20 questions representing application of flexible work in organizations, flexible work schedule, work load and work place were presented in this block. The idea of the third block was to find out employee's satisfaction about existing flexible work practises, their benefits, and directions for future development. Dimension of satisfaction consisted of 19 statements. 17 statements were formulated to identify benefits of flexible work practices and 3 statements were submitted to identify directions for future development. Likert-type five-level scale was used in the questionnaire.

For sample size determination sample size calculator (https://www.surveysystem.com/sscalc.htm\#one) was used. Based on the estimated sample, 400 questionnaires were delivered, using convenience sampling. Data collection was conducted online and by distributing printed questionnaires to respondents. 316 questionnaires were filled out completely and were acceptable for analysis. The details of sample size and response rate are presented in table 3.
Table 3

Population, Sample Size and Response Rate

\begin{tabular}{|c|c|c|c|c|}
\hline $\begin{array}{c}\text { Population } \\
\text { size, } \\
\text { thousand }\end{array}$ & $\begin{array}{c}\text { Confidence } \\
\text { level, \% }\end{array}$ & $\begin{array}{c}\text { Confidence } \\
\text { interval }\end{array}$ & $\begin{array}{c}\text { Sample } \\
\text { size }\end{array}$ & $\begin{array}{c}\text { Response } \\
\text { rate, \% }\end{array}$ \\
\hline $1345,3^{*}$ & 95 & 5 & 385 & 79 \\
\hline
\end{tabular}

*The number of employees (2017, $1^{\text {st }}$ quarter)

The research has been carried out in March - June 2017. The framework of research design is presented on figure 1.

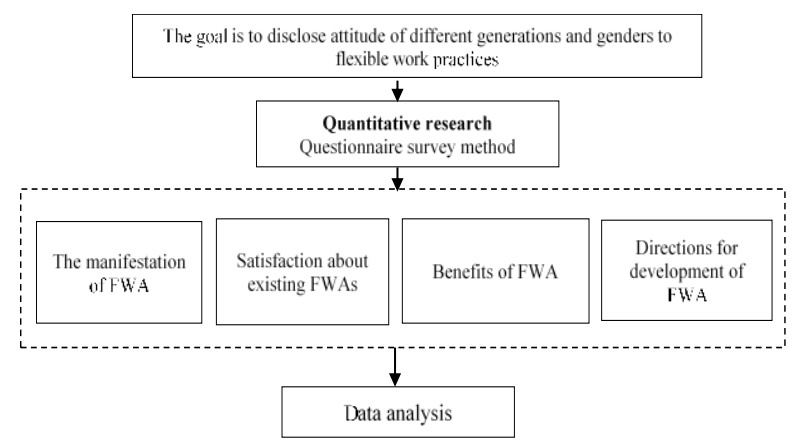

Figure 1. Logical Structure of the Research

For data processing SPSS program package was used. Based on the results of this survey, questionnaire's psychometric characteristics were calculated (see table 4).

Table 4

The values of Cronbach's alpha of factors related to FWA $(\mathrm{N}=316)$

\begin{tabular}{|l|c|c|}
\hline \multicolumn{1}{|c|}{ Criteria } & $\begin{array}{c}\text { N } \\
\text { items }\end{array}$ & $\begin{array}{c}\text { Cronbach's } \\
\text { alpha }\end{array}$ \\
\hline The manifestation of flexible work practises & 20 & 0,69 \\
\hline $\begin{array}{l}\text { Satisfaction about existing flexible work } \\
\text { practises }\end{array}$ & 19 & 0,95 \\
\hline Benefits of flexible practises & 17 & 0,91 \\
\hline $\begin{array}{l}\text { Directions for development of flexible work } \\
\text { arrangement }\end{array}$ & 3 & 0,63 \\
\hline
\end{tabular}


Cronbach's alpha test was used for the reliability of the questionnaire. Having performed analysis of the results, it is seen that obtained values significantly exceed determined minimal limits. Cronbach's alpha coefficient values fluctuate from 0,63 till 0,95 .

\section{Research Findings}

Data were collected from 316 employees (195 women and 121 men). Having analysed application of flexible work options in Lithuanian organizations, there was determined a high expression of flexible work organization that reaches $81,4 \%$.

Having analysed practises of application of separate forms of flexible work organization which respond to groups of work schedule, place and load in more details, it was determined that forms of flexible work schedule and flexible work load dominate in organizations.

The highest approval of respondents in aspect of flexible work schedule was expressed to a possibility to select a convenient time for vacation $(57,1 \%)$, flexible beginning and end of working time $(42,9 \%)$, part-time work $(42,9 \%)$, flexible lunchtime schedule $(38,1 \%)$, flexible working day during a week $(33,3 \%)$.

In the group of flexible work load the highest percentage was determined to following forms: part-time work $(47,6 \%)$, part-time $(42,9 \%)$ and job sharing $(33,3$ $\%)$. The research determined low enough expression of flexible work place, percentage of work at home reaches $23,8 \%$, coordination of work at home and in the office reaches $19 \%$.

Analysis of the research results allowed to identify that respondents gave a priority to development of flexible working schedule $(85,8 \%)$ and possibility to free selection of work load $(81 \%)$. Less assent of respondents was determined for development of flexible working place $(57,3$
$\%)$. Figure 2 presents respondents' attitude to development of forms of desirable flexible work organization.

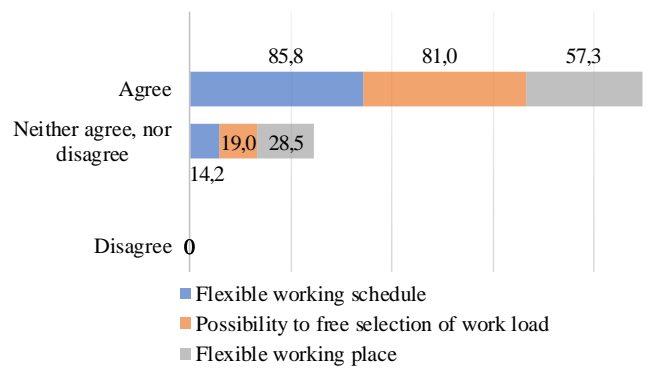

Figure 2. Development of forms of flexible work organization, $\%$

With reference to these results it can be stated that work flexibility in aspect of time and load is more attractive to respondents than flexibility in aspect of work place.

Table 5 presents respondents ' approval/disapproval to the statements responding to the satisfaction in applied forms of flexible work organization from generation perspective.

The research results indicate that respondents are most satisfied in flexible beginning and end of working time, flexible lunch schedule, compressed workweek, part-time work, coordination of work at home and in the office, telework in another remote place and flexible vacation time. Highest discontent was determined for such forms of flexible work organization as work on weekends and work on demand. Having performed more detailed analysis from generation perspective, it should be stated that representatives of generations $\mathrm{B}$ and $\mathrm{Y}$ are most satisfied in the forms of flexible work organization applied in their organizations.

Table 5

Satisfaction in Applied Forms of Flexible Work Organization from Generation Perspective

\begin{tabular}{|c|c|c|c|c|c|c|c|c|c|}
\hline \multirow[b]{3}{*}{$\begin{array}{l}\text { Satisfaction in applied forms of flexible work organization in } \\
\text { the organization }\end{array}$} & \multicolumn{9}{|c|}{ Assessment, \% } \\
\hline & \multicolumn{3}{|c|}{ Unsatisfying } & \multicolumn{3}{|c|}{$\begin{array}{c}\text { Neither satisfying, nor } \\
\text { unsatisfying }\end{array}$} & \multicolumn{3}{|c|}{ Satisfying } \\
\hline & B & $\mathbf{X}$ & $\mathbf{Y}$ & $\mathbf{B}$ & $\mathbf{X}$ & $\mathbf{Y}$ & B & $\mathbf{X}$ & $\mathbf{Y}$ \\
\hline Total time accounting & 25,9 & 25,9 & 0 & 0 & 24,1 & 34,5 & 74,1 & 50,0 & 65,5 \\
\hline Overtime & 0 & 65,1 & 17,2 & 34,1 & 17,4 & 0 & 65,9 & 17,4 & 82,8 \\
\hline Flexible beginning and end of working time & 0 & 0 & 17,2 & 0 & 19,4 & 0 & 100 & 80,6 & 82,8 \\
\hline Shift work & 0 & 16,1 & 34,5 & 34,1 & 49,4 & 17,2 & 65,9 & 34,5 & 48,3 \\
\hline On-call work & 0 & 24,1 & 34,5 & 100 & 25,9 & 33,3 & 0 & 50,0 & 32,2 \\
\hline Flexible lunchtime schedule & 0 & 0 & 0 & 0 & 13,9 & 0 & 100 & 86,1 & 100 \\
\hline Compressed workweek & 0 & 0 & 20,5 & 0 & 19,4 & 41,1 & 100 & 80,6 & 38,4 \\
\hline Part-time work & 0 & 0 & 0 & 0 & 16,3 & 0 & 100 & 83,7 & 100 \\
\hline Work on weekends & 51,7 & 49,4 & 20,5 & 48,3 & 33,3 & 0 & 0 & 17,2 & 58,9 \\
\hline Flexible working time during a week & 0 & 0 & 0 & 51,7 & 50,0 & 0 & 48,3 & 50,0 & 100 \\
\hline Annual working hours & 0 & 0 & 0 & 100 & 65,9 & 41,1 & 0,0 & 34,1 & 58,9 \\
\hline Standby duty at home & 0 & 24,1 & 20,5 & 100 & 50,0 & 41,1 & 0 & 25,9 & 38,4 \\
\hline Coordination of work at home and in the office & 0 & 0 & 20,5 & 0 & 0 & 0 & 100 & 100 & 79,5 \\
\hline Work at home & 0 & 0 & 20,5 & 34,9 & 74,1 & 0,0 & 65,1 & 25,9 & 60,3 \\
\hline Telework in another remote place & 0 & 0 & 20,5 & 0 & 23,7 & 20,5 & 100 & 76,3 & 58,9 \\
\hline Long-term part-time work load & 0 & 26,4 & 61,6 & 34,1 & 54,7 & 0 & 65,9 & 56,6 & 38,4 \\
\hline Job sharing & 48,3 & 19,4 & 28,7 & 51,7 & 59,7 & 0 & 0 & 20,8 & 71,3 \\
\hline Work on demand & 100 & 20,8 & 20,5 & 0 & 58,3 & 0 & 0 & 20,8 & 79,5 \\
\hline Flexible vacation time & 0 & 0 & 0 & 0 & 16,1 & 0 & 100 & 83,9 & 100 \\
\hline
\end{tabular}


Table 6 presents respondents' responses that reflect benefits of flexible work organization from gender perspective.

With reference to the research results it should be highlighted that high percentage of assent is expressed in assessment of both women and men. Benefit of flexible work organization is envisaged by women higher than by men in particular positions. Higher assent was determined for such benefits: helps to coordinate work and family interests; decreases stress, positively affects health; time saving; less costs (for travelling to work, food, outfit); attractive for the persons with children and ability to earn according to needs. And contrary, women do not perceive ecological benefit, better employment possibilities, and possibilities to work with reference to physiological and emotional feeling of the day.

Table 6

Benefits of Flexible Work Organization from Gender Perspective

\begin{tabular}{|c|c|c|c|c|c|c|}
\hline \multirow[b]{3}{*}{ Benefit of flexible work organization } & \multicolumn{6}{|c|}{ Assessment, \% } \\
\hline & \multicolumn{2}{|c|}{ Disagree } & \multicolumn{2}{|c|}{$\begin{array}{c}\text { Neither agree, nor } \\
\text { disagree }\end{array}$} & \multicolumn{2}{|c|}{ Agree } \\
\hline & $\mathbf{W}$ & $\mathbf{M}$ & $\mathbf{W}$ & $\mathbf{M}$ & $\mathbf{W}$ & M \\
\hline Increases working efficiency & 0 & 0 & 42,9 & 37,5 & 57,1 & 62,5 \\
\hline Helps to coordinate work and family interests & 0 & 0 & 0 & 7,1 & 100 & 92,9 \\
\hline Helps to coordinate working and learning activities & 0 & 0 & 7,1 & 0 & 92,8 & 100 \\
\hline Allows to pay more attention to hobbies & 0 & 0 & 14,3 & 0 & 85,7 & 100 \\
\hline Decreases stress, positively affects health & 0 & 0 & 35,7 & 50 & 64,3 & 50 \\
\hline Time saving & 0 & 0 & 35,7 & 37,5 & 64,3 & 62,5 \\
\hline Less costs (for travelling to work, food, outfit) & 0 & 0 & 8,4 & 12,5 & 91,61 & 87,5 \\
\hline Attractive for persons with children & 0 & 0 & 1,4 & 7 & 98,6 & 93 \\
\hline Favourable for persons tendering disabled, elder people & 0 & 0 & 28,6 & 0 & 71,5 & 100 \\
\hline Possibility to work with reference to state of health & 0 & 0 & 28,6 & 0 & 71,4 & 100 \\
\hline $\begin{array}{l}\text { Possibility to work with reference to physiological and emotional } \\
\text { feeling of the day }\end{array}$ & 14,2 & 0 & 21,4 & 0 & 64,2 & 100 \\
\hline Possibility to earn according to needs & 14,3 & 0 & 14,3 & 37,5 & 71,4 & 62,5 \\
\hline Increases employees' loyalty & 7,1 & 12,5 & 35,7 & 25 & 57,1 & 62,5 \\
\hline Improves employer's image & 0 & 0 & 50 & 37,5 & 50 & 62,5 \\
\hline One of the ways to decrease unemployment & 7,1 & 0 & 35,7 & 37,5 & 57,1 & 62,5 \\
\hline Better employment possibilities & 21,4 & 0 & 35,7 & 25 & 42,8 & 75 \\
\hline Ecologically attractive & 7,1 & 0 & 57,1 & 12,5 & 35,7 & 87,5 \\
\hline
\end{tabular}

Table 7 presents the research results about benefits of flexible work organization from generation perspective.

\section{Benefits of Flexible Work Organization from Generation Perspective}

\begin{tabular}{|c|c|c|c|c|c|c|c|c|c|}
\hline \multirow[b]{3}{*}{ Benefit of flexible work organization } & \multicolumn{9}{|c|}{ Assessment, \% } \\
\hline & \multicolumn{3}{|c|}{ Disagree } & \multicolumn{3}{|c|}{$\begin{array}{l}\text { Neither agree, nor } \\
\text { disagree }\end{array}$} & \multicolumn{3}{|c|}{ Agree } \\
\hline & B & $\mathbf{X}$ & $\mathbf{Y}$ & B & $\mathbf{X}$ & $\mathbf{Y}$ & $\mathbf{B}$ & $\mathbf{X}$ & $\mathbf{Y}$ \\
\hline Increases working efficiency & 0 & 0 & 0 & 61,1 & 44,2 & 27,7 & 38,8 & 55,8 & 72,3 \\
\hline Helps to coordinate work and family interests & 0 & 0 & 0 & 0 & 10,9 & 0 & 100 & 89,2 & 100 \\
\hline Helps to coordinate working and learning activity & 0 & 0 & 0 & 0 & 10,9 & 0 & 100 & 89,2 & 100 \\
\hline Allows to pay more attention to hobbies & 0 & 0 & 0 & 0 & 21,7 & 0 & 100 & 78,3 & 100 \\
\hline Decreases stress, positively affects health & 0 & 0 & 0 & 61,1 & 55,8 & 13,9 & 38,8 & 44,2 & 86,2 \\
\hline Time saving & 0 & 0 & 0 & 40,3 & 22,5 & 42,6 & 59,7 & 77,5 & 57,5 \\
\hline Less costs (for travelling to work, food, outfit) & 0 & 0 & 0 & 0 & 10,9 & 42,6 & 100 & 89,2 & 57,5 \\
\hline Attractive for persons with children & 0 & 0 & 0 & 0 & 10,9 & 27,7 & 100 & 89,2 & 72,3 \\
\hline Favourable for persons tendering disabled, elder people & 0 & 0 & 0 & 0 & 21,7 & 27,7 & 100 & 78,3 & 72,3 \\
\hline Possibility to work with reference to state of health & 0 & 0 & 0 & 0 & 32,6 & 0 & 100 & 67,5 & 100 \\
\hline $\begin{array}{l}\text { Possibility to work with reference to physiological and emotional feeling } \\
\text { of the day }\end{array}$ & 0 & 11 & 13,9 & 0 & 21,7 & 13,9 & 100 & 67,4 & 72,3 \\
\hline Possibility to earn according to needs & 0 & 10,9 & 13,9 & 20,8 & 22,5 & 28,7 & 79,2 & 66,7 & 57,5 \\
\hline Increases employees' loyalty & 40,3 & 0 & 0 & 20,8 & 33,3 & 41,6 & 38,9 & 66,6 & 58,5 \\
\hline Improve employer`s image & 0 & 0 & 0 & 61,1 & 33,3 & 41,6 & 38,8 & 66,7 & 58,4 \\
\hline One of the ways to decrease unemployment & 0 & 10,9 & 0 & 40,3 & 33,3 & 28,7 & 59,7 & 55,9 & 71,3 \\
\hline Better employment possibilities & 0 & 21,7 & 0 & 40,3 & 33,3 & 27,7 & 59,7 & 45 & 72,3 \\
\hline Ecologically attractive & 0 & 10,9 & 0 & 40,3 & 43,4 & 27,7 & 59,7 & 45,7 & 72,3 \\
\hline
\end{tabular}

Analysis of results indicated high assent of generation $\mathrm{Y}$ to such benefits: increases working efficiency; decreases stress, positively affects health; creates better employment possibilities and decreases unemployment; ecologically attractive. However, assent of generation $\mathrm{Y}$ to such benefits as time saving, less costs for travelling to work, food, outfit; favour to persons tendering disabled, elder people is less than that of generations $\mathrm{B}$ and $\mathrm{X}$. 


\section{Conclusions}

Technological advancements, changes in global economy, market conditions, workforce composition and life styles call for higher flexibility in work arrangements. The manifestation of individual and employee-oriented practices that permit temporal and spatial flexibility in work processes is constantly increasing.

As a theoretical contribution our study shows that flexible work arrangements are attractive from both employee and employer perspectives, providing the benefits in economic, environmental, social, psychological, and health dimensions. Despite these benefits, the concept of flexibility fit as employees' subjective assessment of the degree to which the flexibility afforded to them at their workplace meets their particular needs and circumstances, is crucial. The types of flexibility that meet the needs of one worker may be quite different than the types of flexibility that meet the needs of another one. Gender and generational differences influence on priorities and expectations towards flexible work options.

The results of empirical research indicate high enough expression of flexible work arrangements in Lithuania. There dominate forms of flexible work schedule and flexible working load in organizations. Respondents are most satisfied by flexible beginning and end of working time, flexible lunchtime schedule, compressed week, parttime work, coordination of work in office and at home, telework in another remote place, and flexible vacation time. Respondents give a priority to development of temporal work flexibility rather than place flexibility.

Analysis in term of generations revealed that representatives of generations $\mathrm{B}$ and $\mathrm{Y}$ are most satisfied in forms of flexible work organization. Generation $\mathrm{Y}$ emphasizes such benefits of FWAs as increase of work efficiency; stress reduction; positive effect on health; better employment possibilities; positive impact on ecology. However, assent of generation $\mathrm{Y}$ to such benefits as time saving; less costs for travelling to work, food, outfit; favourability to persons tendering disabled and elder people is less than that of generations $\mathrm{B}$ and $\mathrm{X}$.

Both women and men see benefits of flexible work organization. Some benefits, as coordination of work and family interests; decrease of stress, positive effect on health; time and cost saving; and ability to earn according to needs women value stronger than men. However, men tend to highlight ecological benefit of FWAs; better employment possibilities, and possibilities to work with reference to physiological and emotional feeling of the day.

Our research revealed attitudes of different sex and age group employees towards flexible work arrangements. Future research could go deeper into analysis and try to investigate correlation between sex, gender, and various forms of flexible work options.

\section{References}

Abrams, J., \& Von Frank, V. (2014). The Multigenerational Workplace-Communicate, Collaborate, and Create Community. Corwin Press. https://doi.org/10.4135/9781483387741

Allen, T. D., \& Eby, L. T. (2016). The Oxford Handbook on Work and Family. Oxford University Press.

Ashoush, M. A. A. L., Elsayed, A. A., \& Younis, R. A. (2015). Flexible Work Arrangements: Related Topics and Directions. Journal of Business Studies Quarterly, 7(1), 36-45.

Benson, J., \& Brown, M. (2011). Generations at Work: Are There Differences and Do They Matter? The International Journal of Human Resource Management, 22(9), 1843-1865. https://doi.org/10.1080/09585192.2011.573966

Booth, A. L., \& van Ours, J. C. (2013). Part-time Jobs: What Women Want? Journal of Population Economics, 26, $263-$ 283. https://doi.org/10.1007/s00148-012-0417-9

Buonocore, F., Russo, M., \& Ferrara, M. (2015). Work-family Conflict and Job Insecurity: Are Workers from Different Generations Experiencing True Differences? Community, Work \& Family, 18(3), 299-316. https://doi.org/10.1080/ 13668803.2014.981504

Carlson, D. S., Ferguson, M., Kacmar, K. M., Grzywacz, J. G., \& Whitten, D. (2011). Pay It Forward: The Positive Crossover Effects of Supervisor Work-Family Enrichment. Journal of Management, 37(3), 770-789. https://doi.org/10.1177/0149206310363613

Casper, W. J., \& Harris, Ch. M. (2008). Work-life Benefits and Organizational Attachment: Self-interest Utility and Signalling Theory Models. Journal of Vocational Behaviour, 72(1), 95-109. https://doi.org/10.1016/ j.jvb.2007.10.015

Choo, J. L. M., Desa, N. M., \& Asaari, M. H. A. H. (2016). Flexible Working Arrangement Toward Organizational Commitment and Work-Family Conflict. Studies in Asian Social Science, 3(1), 21-36.

Cotti, C. D., Haley, M. R., \& Miller, L. A. (2014). Workplace Flexibilities, Job Satisfaction and Union Membership in the US Workforce. British Journal of Industrial Relations, 52, 403-425. https://doi.org/10.1111/bjir.12025

Dutcher, E. G. (2012). The Effects of Telecommuting on Productivity: An Experimental Examination. The Role of Dull and Creative Tasks. Journal of Economic Behaviour \& Organization, 84(1), 355-363. https://doi.org/10.1016/j.jebo.2012.04.009 
Eldridge, D., \& Nisar, T. M. (2011). Employee and Organizational Impacts of Flexitime Work Arrangements. Industrial Relations, 66(2), 213-234. https://doi.org/10.7202/1006144ar

Fry, R. (2015). Millennials Surpass Gen Xers as the Largest Generation in U.S. Labour Force. Pew Research Centre. Available from internet: http://www.pewresearch.org/fact-tank/2015/05/11/millennials-surpass-gen-xers-as-thelargest-generation-in-u-s-labor-force/

Gajendran, R. S., \& Harrison, D. A. (2007). The Good, the Bad, and the Unknown About Telecommuting: Meta-Analysis of Psychological Mediators and Individual Consequences. Journal of Applied Psychology, 92(6), 1524 -1541. https://doi.org/10.1037/0021-9010.92.6.1524

Giannikis, S. K., \& Dimitrios, M. (2011). Flexible Work Arrangements in Greece: a Study of Employee Perceptions. The International Journal of Human Resource Management, 22(2), 417-432. https://doi.org/10.108 0/09585192.2011.540163

Gordon, C. E. (2014). Flexible Workplace Practices: Employees' Experiences in Small IT Firms. Industrial Relations. 69(4), 766-784. https://doi.org/10.7202/1028111ar

Haar, J. M., Russo, M., Sune, A., \& Ollier-Malaterre, A. (2014). Outcomes of Work-life Balance on Job Satisfaction, Life Satisfaction and Mental Health: a Study Across Seven Cultures. Journal of Vocational Behaviour, doi:10.1016/j.jvb.2014.08.010

Heathfield, S. M. (2016). Advantages and Disadvantages of Flexible Work Schedules? Available from internet: https://www.thebalance.com/advantages-and-disadvantages-of-flexible-work-schedules-1917964

Hyondong, K., \& Yaping, G. (2016). Effects of Work-family and Family-work Conflicts on Flexible Work Arrangements Demand: a Gender Role Perspective. The International Journal of Human Resource Management, 121. http://dx.doi.org/10.1080/09585192.2016.1164217

Joyce, K. E., Hall, B. J., Armstrong, R., Doyle, J., \& Bambra, C. (2010). Snakes and Ladders: Challenges and Highlights of the First Review Published with the Cochrane Public Health Review Group. Journal of Public Health, 32(2), 283-285. https://doi.org/10.1093/pubmed/fdq026

Kelliher, C., \& D. Anderson (2010). Doing More with Less? Flexible Working Practices and the Intensification of Work. Human Relations, 63(1), 83-106. https://doi.org/10.1177/0018726709349199

Lake, A. (2013). Smart Flexibility. Moving Smart and Flexible Working from Theory to Practice. Routledge.

Lee, B. Y., \& DeVoe, S. E. (2012). Flextime and Profitability. Industrial Relations: A Journal of Economy and Society, 51(2), 298-316. https://doi.org/10.1111/j.1468-232X.2012.00678.x

Lub, X. D., Bal, P. M., Blomme, R. J., \& Schalk, R. (2016). One job, One Deal...or Not: Do Generations Respond Differently to Psychological Contract Fulfilment? The International Journal of Human Resource Management, 27(6), 653-680. https://doi.org/10.1080/09585192.2015.1035304

McNall, L. A, Nicklin, J. M., \& Masuda, A. D. (2010). A Meta-Analytic Review of the Consequences Associated with Work-Family Enrichment. Journal of Business and Psychology, 25(3), 381-396. https://doi.org/10.1007/s10869-009-9141-1

Pitt-Catsouphes, M., \& Matz-Costa, Ch. (2008). The Multi-generational Workforce: Workplace Flexibility and Engagement. Community, Work \& Family, 11, 215-222. https://doi.org/10.1080/13668800802021906

Pitt-Catsouphes, M., Matz-Costa, Ch., \& Besen, E. (2009). Workplace Flexibility: Findings from the Age \& Generations Study. The Sloan Centre on Aging \& Work. Issue brief, 19, 1-21.

Possenriede, D. S. (2014). The economics of temporal and locational flexibility of work. Ridderprint, Ridderkerk.

Russell, H., O'Connell, P., \& McGinnity, F. (2009). The Impact of Flexible Working Arrangements on Work-life Conflict and Work Pressure in Ireland. Gender, Work \& Organization, 16(1), 73-97. https://doi.org/10.1111/j.14680432.2008.00431.x

Shockley, K. M., \& Allen, T. D. (2007). When Flexibility Helps: Another Look at the Availability of Flexible Work Arrangements and Work-family Conflict. Journal of Vocational Behaviour, 71(3), $479-493$. https://doi.org/10.1016/j.jvb.2007.08.006

Stirpe, L., \& Zarraga-Oberty, C. (2017). Are High-Performance Work Systems Always a Valuable Retention Tool? The Roles of Workforce Feminization and Flexible Work Arrangements. European Management Journal, 35(1), 128136. https://doi.org/10.1016/j.emj.2016.04.002

Sun, J., \& Wang, X. (2010). Value Differences Between Generations in China: a Study in Shanghai. Journal of Youth Studies, 13(1), p.65-81. https://doi.org/10.1080/13676260903173462 
Ramune Ciarniene, Milita Vienazindiene. Flexible Work Arrangements from Generation and Gender Perspectives....

Taylor, T. C. (2016). Workplace Flexibility for Millennials: Appealing to a Valuable New Generation. Available from internet: https://www.adp.com/thrive/articles/workplace-flexibility-for-millennials-appealing-to-a-valuable-new-gen eration-3-324.

Thompson, R. J., Payne, S. C., \& Taylor, A. B. (2015). Applicant Attraction to Flexible Work Arrangements: Separating the Influence of Flextime and Flexplace. Journal of Occupational and Organizational Psychology, 88(4), 726-749. https://doi.org/10.1111/joop.12095

Tolbize, A. (2008). Generational Differences in the Workplace. Research and Training Centre on Community Living. Available from internet: http://rtc.umn.edu/docs/2_18_Gen_diff_workplace.pdf

Townsend, K., McDonald, P., \& Cathcart, A. (2016). Managing Flexible Work Arrangements in Small Not-for-profit Firms: the Influence of Organisational Size, Financial Constraints and Workforce Characteristics. The International Journal of Human Resource Management, 29, 1-23.

The article has been reviewed. Received in October, 2017; accepted in February, 2018. 